\title{
Impact of Operational Efficiency and Customer Satisfaction on Banking Performance: Empirical Examination on UAE Islamic Banking
}

\author{
Mansoor Mulla, Osama Isaac, Ibrahim Alrajawy, Amiya Bhaumik
}

\begin{abstract}
The primary aim of the research is to examine the effect of operational efficiency and customer satisfaction in case of Islamic banking performance in UAE. Proposed model's evaluation was done using questionnaire survey data that was obtained from 158 valid responses from Customer Service Officers, Bank Managers, Front Line Officers, and Assistant Manager working in the Islamic banks of UAE. Structural Equation Modelling via PLS3.0 software was used to define the crucial levels of associations and interactions between the tested factors. The proposed model, as evidenced by the goodness of fit of the model to the data, explained $39 \%$ of the variance in the Islamic banking performance. The multivariate analysis showed a major impact of operational efficiency on Islamic banking performance as compared to the impact on customer satisfaction. The study results gave insights into the strategies of Islamic banking system.
\end{abstract}

Keywords: Operational efficiency; customer satisfaction; Islamic banking; performance; $U A E$

\section{INTRODUCTION}

Financial institutions are considered as the backbone of the world economic system, which provides capital for innovation, creation of job, infrastructure development, and prosperity. However, banks play an important part in the community, which has a direct impact on individual spending and it has an impact on the growth and development of an entirely new industry, for example, ICT [1].

Islamic finance was initially experimented in Egypt in 1963 abiding by Islamic Sharia'a laws and principles, and many Islamic banks were later founded in basically in the Middle East and Asia. The growth of Islamic finance has been high in terms of not only its popularity but also the areas of finance ventured in and the number of countries in which it is operating. In the UAE there is 8 full-fledged Islamic banks, as well as 23 commercial banks with Islamic bank windows which contributes significantly to the economic development of the country. Furthermore, Islamic finance and banking is still new to the population of the word and is still in the progress of making its success stories at the scale of the performance of commercial finance and banking. It is clear

Revised Manuscript Received on September 25, 2019

Mansoor Mulla, Lincoln University College, Selangor, Malaysia. Email: xyz1@blueeyesintlligence.org

Osama Isaac, Lincoln University College, Selangor, Malaysia. Email: xyz2@blueeyesintlligence.org

Ibrahim Alrajawy, Lincoln University College, Selangor, Malaysia. Email: xyz3@blueeyesintlligence.org

Amiya Bhaumik, Lincoln University College, Selangor, Malaysia. Email: xyz3@blueeyesintlligence.org that the UAE is trying to become a leading technology centre based on the innovation strategy of the 4th Industrial Revolution [2, 3]. Governments, organizations, and Individuals should pay the greatest attention to the planning and implementation of information technology in all its aspects of business, especially in the age of digitalization. In the age of digitalization, which is known as Industry 4.0 or 4 th industrial revolution [4].

As per a study led by Tabash \& Dhankar (2014) [5] Islamic finance hypothesis advances economic improvement through its immediate connection to the genuine economic and physical exchanges, its rejections for hurtful items and exercises, and the advancement of economic development and communal equity.

Overall, by reviewing literature, it is clearly evident that significant studies particularly investigating the determinants of performance of Islamic and commercial banks are limited in the UAE. Only a few relevant and significant studies in the context of the UAE was noted. However, his study was also limited to the duration of 1996-2008, where the effect of global financial crisis was not clearly inevitable. Thus, the study aims at evaluating the regulating factors that affects the performance of Islamic banks in the UAE. In most contemporary organizations, adopting technology is not only uses ICT for filling up forms and records but also as a tool that carries out the work of identification, accumulation, analysis, measurement, preparation, interpretation and communication of information needed as per the planning of the management In addition, it is also used in the evaluation of organization and assure appropriate use of resources and setting up accountability.

\section{LITERATURE REVIEW}

\section{A. Operational Efficiency (OE)}

Operational efficiency is identified as the bank's tactical planning to keep a strong balance between costs, revenue, and productivity. It is said that efficient banks have the ability to maintain their market and survive from the competitive market, while inefficient banks will be eliminated eventually [6]. There are number studies that scrutinised the association between operational efficiency and banking performance. There are various internationally recognized set of measures that are determined by the different global indicators in order to determine UAE's global position [7-10]. A study of Guru, Shanmugam, Alam, \& Perera (2003) [6], which was based on Malaysian banks determined

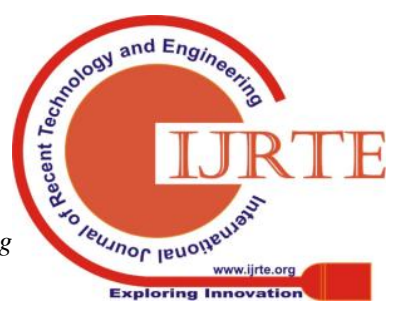


why some banks more effective than others, and to what degree the profitability disparities are owing to differences in the management of internal factors rather than external environmental factors. Guru et al., (2002) [11] also found that that efficient expense management is the one of the critically significant factors in explaining high banking performance. Their study confirmed that efficiency relating to expenses-management is a significant driver of bank profitability as banks can consequently improve their performance by directing the attention on appropriate cost controls and operating efficiency. Reporting the similar result, Safiullah (2010) [12] showed that commercial banks were better in operational efficiency than Islamic banks in term of productivity. The study analysed banks from numerous transition countries, and found significant relationship between operational efficiency and performance. Sensarma (2006) [13] investigated the Indian banking industry and found the same. Williams \& Nguyen (2005) [14] analysed profit efficiency and bank governance in South-East Asia and found a significant association between two variables. The proposed hypothesis has been stated below:

H1: Operational efficiency has a positive impact on the Islamic banking performance.

\section{B. Customer Satisfaction (CS)}

CS refers to the way of measuring how the products and services are offered by an organization in order to meet or exceed customers' expectations [15].Customer satisfaction is referred as the number of customers, whose stated experience (ratings) with an organisation, its products and services surpasses specified satisfaction objectives [16].

Few literature studies have considered the relationship between CS and banking services, which has also been studied as a different determinant of gauging the performance of the banking sector. Jham \& Khan (2008) [17] stated that variable adoption of customer satisfaction can be a determinant of better performance. They also showed the linkage of CS with that of the banking performance. In addition to this, Sarigiannidis, Keisidou, Maditinos, \& Thalassinos (2013) [18] showed a completely opposite result in which no significant link was obtained between CS and banking performance in Greece. Ehigie (2006) [19], and Ndubisi (2006) [20], showed that CS is linked with customer behaviour and their tendency of selecting a bank. There needs to be further studies considering CS and its impact on Islamic banking performance. Based on this, following hypothesis has been derived:

$\mathrm{H} 2$ : Customer satisfaction has a positive effect on Islamic banking performance.

\section{Islamic Banking Performance (IBP)}

Organizational performance factor is one of the most significant parameters in the research related to management and perhaps the most significant guide to the overall performance of the organization [21]. The organizational performance is a benchmark or an indicator for efficiency, effectiveness, and environmental obligation like productivity, time of cycle, reduction of waste, and compliance of rules [22]. The large amount of definitions serve to view the performance of the organisations as a tool for achieving objectives [23]. In short, the performance of the organisation is the most significant factor in evaluation of organisations, their activities, and the environments in which they work.

Despite all the facts and significant development of Islamic banking, the literature has still shown the lack of focus toward the efficiency of the Islamic banks [24]. Since, it is found that most of the studies and researches in literature are generally focusing on the presentation of two types of banks; the Islamic financial intermediaries and the conventional banks with respect to the relationship between the features of the banks and their profitability. For instance, Khrawish (2011) [25] utilised bank level data in their researches and performed regression analysis in order to scrutinize the determinants associated with the performance of the Islamic Banks. Similarly, Sufian (2007) [26] conducted a study on the working of Islamic banking in Bangladesh in order to measure the efficiency of banks by using Banking Efficiency Model. In this research, researcher confirmed that the Islamic banks have potential to stay dynamic even in the conventional banking architecture where the profit and loss sharing methods of investments are of minimum dominance. Along with this, the researcher also found that the financial services and financial products in the Islamic the banking system possess different risk aspects therefore different prudential regulations have to be adopted [12]. The recent automation and data exchange trend in the field of manufacturing technologies includes cyber-physical systems, the IoT, cloud computing and cognitive computing.

\section{RESEARCH METHODOLOGY}

\section{A. Overview of the Proposed Conceptual Framework}

In this study, the primary objective is to investigate the relationship between operational efficiency, and customer satisfaction and the Islamic banking performance. An extensive review of literature has highlighted the variables of this study and RBV as underpinning theory. In this regard, operational efficiency, and customer satisfaction are deemed to be a distinct intangible competitive advantage resource. Figure 1 depicts the proposed conceptual model that includes operational efficiency, and customer satisfaction and the Islamic banking performance.

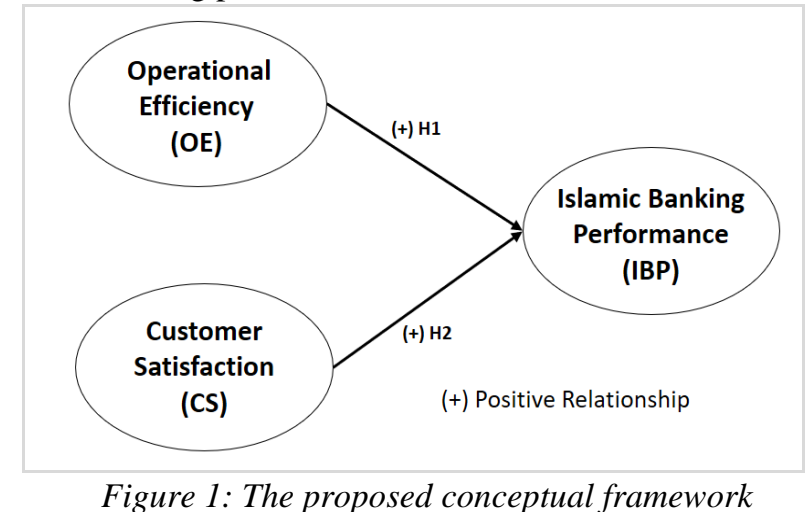

\section{B. Development of Instrument and Data collection}

The survey research was carried out in the UAE's banks within a period of six months beginning from April 2018 to end of September 2018. This 
study distributed 200 questionnaire copies and expected a high response rate, and the final collected data samples numbered 158 from Customer Service Offers, Bank Managers, Front Line Officers, and Assistant Manager in the Islamic banks in the UAE. A random sample sampling was used as per Creswell (2003) [27]. The questionnaire collected data are analysed with the help of analytical methods, and in the present study, data analysis was conducted with the help of Statistical Package of Social Sciences (SPSS), version 22.0 and Smart PLS3.0. The data analysis methods adopted based on their research questions and the characteristics of the variables as recommended by Byrne (2010) [28]. Variables were measured using a Likert Scale which recommended in the previous studies.

\section{DATA ANALYSIS AND RESULTS}

PLS (Partial Least Squares) SEM-VB (Structural Equation Modelling-Variance Based) was employed to assess the research model by utilising the software SmartPLS 3.0 [29]. A two-phase analytical technique consisting of (i) measurement model analysis (reliability and validity) and (ii) structural model analysis (examining the conceptualised relationships) was employed after performing the descriptive assessment.

\section{A. Descriptive Analysis}

Table 1 exhibits the mean and SD for every variable. The respondents presented their opinion with respect to their operational efficiency, CS, and Islamic banking performance based on a 5-point scale ranging from 1 (strongly disagree) to 5 (strongly agree). Islamic banking performance score the highest with mean 4.078 out of 5.0, with a standard deviation of 0.433 .

\section{B.Units}

Construct reliability as well as validity (comprising Table 1: Measurement model assessment

\begin{tabular}{|c|c|c|c|c|c|c|c|}
\hline Constructs & Item & $\begin{array}{c}\text { Loading } \\
(>0.7)\end{array}$ & M & SD & $\begin{array}{c}\alpha \\
(>0.7)\end{array}$ & $\begin{array}{c}\mathrm{CR} \\
(>0.7)\end{array}$ & $\begin{array}{c}\text { AVE } \\
(>0.5)\end{array}$ \\
\hline \multirow{7}{*}{$\begin{array}{c}\text { Operational } \\
\text { Efficiency (OE) }\end{array}$} & OE1 & 0.769 & \multirow{7}{*}{3.947} & \multirow{7}{*}{0.602} & \multirow{7}{*}{0.890} & \multirow{7}{*}{0.917} & \multirow{7}{*}{0.648} \\
\hline & $\mathrm{OE} 2$ & 0.713 & & & & & \\
\hline & OE3 & 0.805 & & & & & \\
\hline & $\mathrm{OE} 4$ & 0.873 & & & & & \\
\hline & OE5 & 0.793 & & & & & \\
\hline & OE6 & Deleted & & & & & \\
\hline & OE7 & 0.864 & & & & & \\
\hline \multirow{7}{*}{$\begin{array}{c}\text { Customer } \\
\text { Satisfaction (CS) }\end{array}$} & CS1 & Deleted & \multirow{7}{*}{4.046} & \multirow{7}{*}{0.603} & \multirow{7}{*}{0.908} & \multirow{7}{*}{0.928} & \multirow{7}{*}{0.682} \\
\hline & $\mathrm{CS} 2$ & 0.788 & & & & & \\
\hline & $\mathrm{CS} 3$ & 0.876 & & & & & \\
\hline & CS4 & 0.865 & & & & & \\
\hline & CS5 & 0.844 & & & & & \\
\hline & CS6 & 0.814 & & & & & \\
\hline & CS7 & 0.760 & & & & & \\
\hline \multirow{7}{*}{$\begin{array}{l}\text { Islamic Banking } \\
\text { Performance } \\
\text { (IBP) }\end{array}$} & IBP1 & Deleted & \multirow{7}{*}{4.078} & \multirow{7}{*}{0.433} & \multirow{7}{*}{0.840} & \multirow{7}{*}{0.887} & \multirow{7}{*}{0.611} \\
\hline & IBP2 & 0.716 & & & & & \\
\hline & IBP3 & 0.818 & & & & & \\
\hline & IBP4 & 0.772 & & & & & \\
\hline & IBP5 & 0.744 & & & & & \\
\hline & IBP6 & Deleted & & & & & \\
\hline & IBP7 & 0.851 & & & & & \\
\hline
\end{tabular}

Note: $\mathrm{M}=$ Mean; $\mathrm{SD}=$ Standard Deviation, $\alpha=$ Cronbach's alpha; $\mathrm{CR}=$ Composite Reliability, AVE $=$ Average Variance Extracted.

The degree to which the articles distinguish among concepts or measure different constructs is demonstrated by discriminant validity. The heterotrait-monotrait ratio discriminant and convergent validity) were used to examine the measurement model. The particular alpha coefficients of Cronbach were tested to determine the reliability of every core parameter in the measurement model (construct reliability). The quantities of all the unique alpha coefficients of Cronbach in this research ranged from 0.840 to 0.908 , which went beyond the proposed value of 0.7 [30]. Moreover, for inspecting construct reliability, all the CR (composite reality) values ranged from 0.887 to 0.928 , which went beyond 0.7 [31, 32]. Thus, as Table 1 shows, construct reliability has been fulfilled as Cronbach's CR and alpha were rather error-free for all the parameters.

Analysis of indicator reliability was conducted by utilising factor loadings. When the related indicators are very similar, this is reflected in the construct and signified by the construct's high loadings [33]. The exceeding of values beyond 0.70 suggests substantial factor loadings. Table 1 displays that all items in this research had factor loadings greater than the suggested value except for items OE6, CS1, IBP1, and IBP6 which were eliminated from the scale due to low loadings..

AVE (average variance extracted) was employed in this study to analyse convergent validity, which represents the degree to which a measure is correlated positively with the same construct's other measures. All the AVE values ranged from 0.611 and 0.682 , which went beyond the proposed value of 0.50 . Thus, all constructs have complied with the convergent validity acceptably, as shown in Table 1.
(HTMT) was employed to analyse the measurement model's discriminant validity.

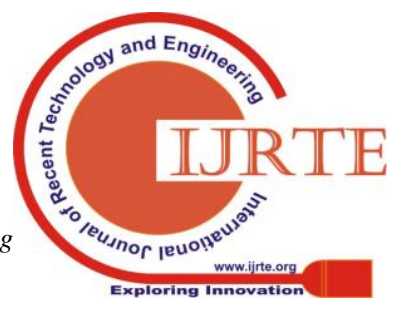


The HTMT of correlations based on the multitrait-multi method matrix. HTMT has been used to test discriminant validity in this study. The discriminant validity poses certain issues when the HTMT value is higher than the HTMT0.90 value of 0.90 or HTMT0.85 value of 0.85 [32], but Table 2 shows that all the HTMT values were less than the 0.85 , hence fulfilling the discriminant validity requirement.

Table 2: HTMT criterion
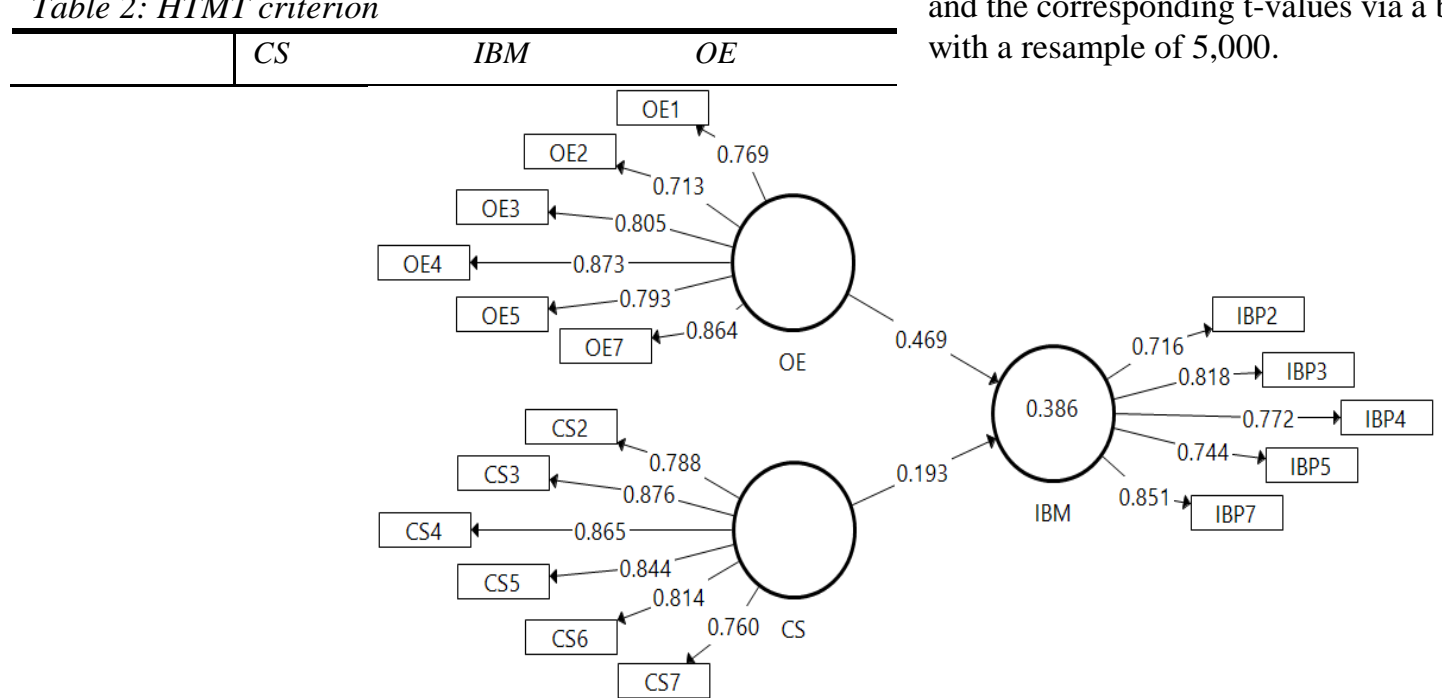

Key: OE: Operational Efficiency, CS: Customer Satisfaction, IBP: Islamic Banking Performance

Figure 2: PLS algorithm results

Figure 2 and Table 3 depict the structural model assessment, showing the results of the hypothesis tests. Operational Efficiency and customer satisfaction positively influence Islamic banking performance. Hence, $\mathrm{H} 1$ and $\mathrm{H} 2$ are accepted with $\quad(\beta=0.469, \mathrm{t}=4.628, \mathrm{p} \quad<0.001) \quad$ and $(\beta=0.193, \mathrm{t}=1.703, \mathrm{p}<0.05)$, respectively. Thirty-nine percent of the variance in Islamic banking performance is explained by Operational Efficiency and customer satisfaction. The values of $\mathrm{R}^{\mathbf{2}}$ have an acceptable level of explanatory power, indicating a substantial model [34].

Table 3: Structural path analysis result

\begin{tabular}{cllllll}
\hline \hline Hypothesis & Relationship & Std Beta & Std Error & t-value & p-value & Decision \\
\hline H1 & OE $\rightarrow$ IBP & 0.469 & 0.101 & 4.628 & 0.000 & Supported \\
H2 & CS $\rightarrow$ IBP & 0.193 & 0.113 & 1.703 & 0.044 & Supported \\
\hline \hline
\end{tabular}

Key: OE: Operational Efficiency, CS: Customer Satisfaction, IBP: Islamic Banking Performance

\section{DISCUSSION}

The main objective of this study is to investigate the Islamic banking performance predictors. And based on the literature two hypothesis were developed to fulfil the main objective and the discussion of these two hypothesis is below:

First hypotheses was to examine the impact of operational efficiency on the Islamic banking performance. This hypothesis was empirically tested and results showed that there is a significant direct positive impact of the operational efficiency on the performance of the Islamic banking with $(\beta=0.469, \mathrm{t}=4.628, \mathrm{p}<0.001)$. Thus $\mathrm{H} 1$ was supported. These results are in consistent with the findings of Farris et al. (2010) [16], Guru et al. (2002) [11], Safiullah (2010) [12], Sensarma (2006) [13], and Williams \& Nguyen (2005) [14]. For instance, Guru et al. (2002) [11] found that that efficient expense and cost management has been a critical and significant dimension in explaining greater banking profitability and performance.

Second, H2 was developed and formulated stating that customer satisfaction is a significant predictor of the performance of Islamic banking. Results revealed that customer satisfaction is a great positive predictor of Islamic banking performance with $(\beta=0.193, \mathrm{t}=1.703, \mathrm{p}<0.05)$. Hence, second hypotheses was supported. This result is in consistent with Ehigie (2006) [19], Jham \& Khan (2008) [17], Ndubisi (2006) [20]. For instance, Jham \& Khan (2008) [17] showed adopting the customer satisfaction-related variables could improve banking performance, while Ndubisi (2006) [20] revealed that customer satisfaction influence customers to have a stronger relationship with the bank. The finding of this study, however, was contradictory with Sarigiannidis et al. (2013) [18] who found that customer satisfaction does not have a significant effect on the banks' performance. Hence, the result of this study supports that Islamic banks in the UAE are positively and significantly influenced by customer satisfaction.

Finally, the two hypothesis of this research were supported and results found that operational efficiency and customer satisfaction have positive direct impact on the Islamic banking performance in the UAE. Ultimately the variance explained in this study is $39 \%$ which is considered substantial model. 


\section{CONCLUSION}

In order to systemically identify the factors that are likely to affect Islamic banks in the UAE, literature review was conducted, and thus a conceptual model that consisted of two factors (operational efficiency, and customer satisfaction) were hypothesised to have a significant and positive impact on Islamic bank performance. The researcher conducted this study in view of the fact that more detailed picture about bank performance and their critical factors can statistically be investigated by using questionnaire method as it provides an insight into different views and opinions of banking professionals in the UAE with regard to operational efficiency, and customer satisfaction. Results revealed that both variables predicted the performance of Islamic banking positively and thus achieved the main objective of the study. Total variance explained by the proposed factors is $39 \%$ of the performance in Islamic banks in the UAE. In the UAE, the importance of the banking sector to the country is reflected by its contribution on GDP (10\%) [36]. Thus we need to focus on the performance of the banking and financing system in the UAE.

\section{APPENDIX \\ APPENDIX A}

INSTRUMENT FOR VARIABLES

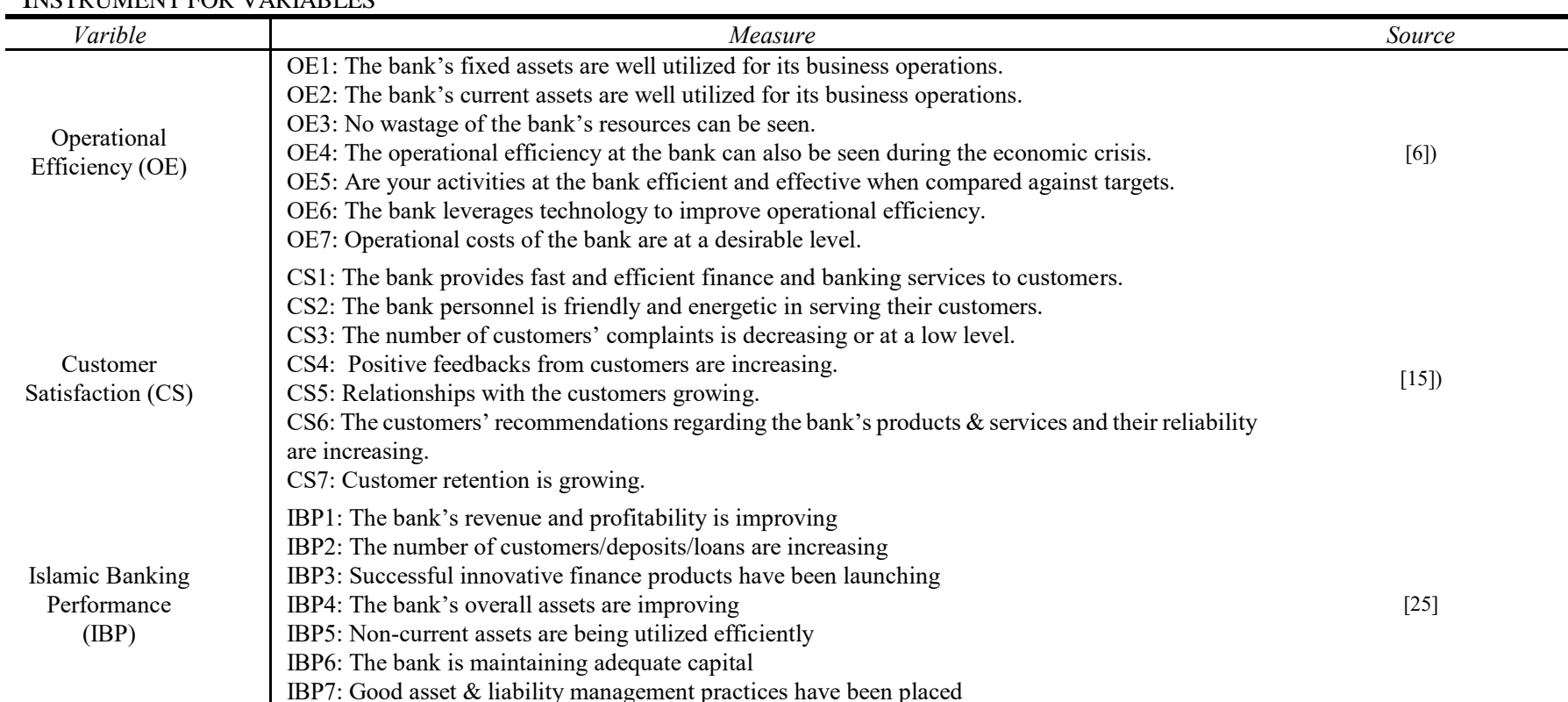

\section{REFERENCES}

1. D. Cogan, (2008). Corporate Governance and Climate Change: The Banking Sector.

2. A. S. Alkhateri, A. E. Abuelhassan, G. S. A. Khalifa, M. Nusari \& A. Ameen, (2018). The Impact of perceived supervisor support on employees turnover intention: The Mediating role of job satisfaction and affective organizational commitment. International Business Management, 12(7), pp. 477-492.

3. A. Ameen, H. Almari \& O. Isaac, (2019). Determining Underlying Factors that Influence Online Social Network Usage Among Public Sector Employees in the UAE. In Fathey M. Faisal Saeed, Nadhmi Gazem (Ed.), Recent Trends in Data Science and Soft Computing. IRICT 2018. Advances in Intelligent Systems and Computing Recent Tre, 843, pp. 945-954. Springer Nature Switzerland AG: Springer International Publishing.

4. N. Lwin, A. Ameen \& M. Nusari, (2019). Mobile Banking Adoption among Customers within Private Commercial Banking Sector in Yangon , Myanmar. International Journal of Management and Human Science (IJMHS), 3(2), pp. 44-59.

5. M. I. Tabash \& R. S. Dhankar, (2014). Islamic Finance and Economic Growth: An Empirical Evidence from United Arab Emirates (UAE ). Journal of Emerging Issues in Economics, Finance and Banking, 3(2),

6. B. K. Guru, J. Staunton \& B. Shanmugam, (2002). Determinants of commercial bank profitability in Malaysia. Journal of Money, Credit, and Banking 17.

7. W. Al-Ali, A. Ameen, O. Issac, M. Nusari \& Ibrhim Alrajawi. (2018). Investigate the Influence of Underlying Happiness Factors on the Job Performance on the Oil and Gas Industry in UAE. International Journal of Management and Human Science (IJMHS), 2(4), pp. 32.

8. F. Al-Obthani, A. Ameen, M. Nusari \& I. Alrajawy, (2018). Proposing SMART-Government Model: Theoretical Framework. International pp. 1069-1085.

Journal of Management and Human Science (IJMHS), 2(2), pp 27-38.

9. R. Al-Shamsi, A. Ameen, O. Isaac, A. H. Al-Shibami \& G. Sayed Khalifa, (2018). The Impact of Innovation and Smart Government on Happiness: Proposing Conceptual Framework. International Journal of Management and Human Science (IJMHS), 2(2), pp. 10-26.

10. A. Haddad, A. Ameen, \& M. Mukred, (2018). The Impact of Intention of Use on the Success of Big Data Adoption via Organization Readiness Factor. International Journal of Management and Human Science (IJMHS), 2(1), pp. 43-51.

11. B. Guru, B. Shanmugam, N. Alam \& J. Perera, (2003). An Evaluation of Internet Banking Sites In Islamic Countries. Journal of Internet Banking and Commerce 8.

12. M. Safiullah, (2010). Superiority of Conventional Banks \& Islamic Banks of Bangladesh: A Comparative Study. International Journal of Economics and Finance 2.

13. R. Sensarma, (2006). Are foreign banks always the best? Comparison of state-owned, private and foreign banks in India. Economic Modelling, 23(4), pp. 717-735.

14. J. Williams \& N. Nguyen, (2005). Financial liberalisation, crisis, and restructuring: A comparative study of bank performance and bank governance in South East Asia. Journal of Banking \& Finance, 29(8), pp. 2119-2154.

15. G. Radmila, V. Dejan \& B. Milan, (2014). Market niche for Microfinancing-An evidence from Serbia. In Third International Scientific Conference on employment, education and entrepreneurship. Serbia.

16. P. W. Farris, N. Bendle, P. Pfeifer \& D. Reibstein, (2010). Marketing Metrics: The Definitive Guide to Measuring Marketing Performance. Pearson Education.

17. V. Jham \& K. M. Khan, (2008). Determinants of performance in retail banking: Perspectives of customer satisfaction and relationship marketing. Singapore Management Review 30.

18. L. Sarigiannidis, E. Keisidou, D I. Maditinos \& E. I. Thalassinos, 
(2013). Customer satisfaction, loyalty and financial performance: A holistic approach of the Greek banking sector. International Journal of Bank Marketing, 31(4), pp. 259-288.

19. B. O. Ehigie, (2006). Correlates of customer loyalty to their bank: a case study in Nigeria. International Journal of Bank Marketing, 24(7), pp. 494-508.

20. N. Ndubisi, (2006). A structural equation modelling of the antecedents of relationship quality in the Malaysia banking sector. Journal of Financial Services Marketing 11.

21. C. Gavrea, L. Ilies, \& R. Stegerean, (2011). Determinants of organizational performance: The case of Romania. Management \& Marketing, 6(2), pp. 285-300.

22. W. N. MUCHIRA, (2013). RELATIONSHIP BETWEEN STRATEGY IMPLEMENTATION AND PERFORMANCE IN COMMERCIAL BANKS IN KENYA. UNIVERSITY OF NAIROBI.

23. I. Abu-Jarad, N. Yusof \& D. Nikbin, (2010). A review paper on organizational culture and organizational performance. International Journal of Business and Social Science 1.

24. M. Cihak \& H. Hesse, (2010). Islamic Banks and Financial Stability: An Empirical Analysis. IMF Working Papers 38.

25. H. A. Khrawish, (2011). Determinants of Commercial Banks Performance: Evidence from Jordan. International Research Journal of Finance and Economics 81.

26. F. Sufian, (2007). The efficiency of Islamic banking industry in Malaysia. Humanomics: The International Journal of Systems and Ethics 23.

27. J. W. Creswell, (2003). Research design Qualitative quantitative and mixed methods approaches. Research Design Qualitative Quantitative and Mixed Methods Approaches, pp. 3-26.

28. B. M. Byrne, (2010). Structural Equation Modeling With AMOS Basic Concepts, Applications, and Programming (2nd ed.). Routledge.

29. C. M. Ringle, S. Wende \& J.-M. Becker, (2015). SmartPLS 3 Bonningstedt: SmartPLS.

30. V. R. Kannana \& K. C. Tan, (2005). Just in time, total quality management, and supply chain management: understanding their linkages and impact on business performance. Omega: The International Journal of Management Science, 33(2), pp. 153-162.

31. C. E. Werts, R. L. Linn \& K. G. Jöreskog, (1974). Intraclass reliability estimates: Testing structural assumptions. Educational and Psychological Measurement, 34(1), pp. 25-33.

32. R. B. Kline, (2010). Principles and practice of structural equation modeling (3rd ed.). New York: The Guilford Press.

33. J. F. J. Hair, G. T. M. Hult, C. Ringle \& M. Sarstedt, A Primer on Partial Least Squares Structural Equation Modeling (PLS-SEM), 46 Long Range Planning § (2014). London: Thousand Oaks: SAGE.

34. J. Cohen, (1988). Statistical Power Analysis for the Behavioral Sciences (2nd Editio). LawreAssociatesnce Erlbaum.

35. UAE Bank Federation. (2015). Role of Banks in the UAE. https://doi.org/https://doi.org/10.1016/j.jbankfin.2005.03.011

\section{AUTHORS PROFILE}

Mansoor Mulla profile which contains their education details, their publications, research work, membership, achievements, with photo that will be maximum 200-400 words.

Osama Isaac profile which contains their education details, their publications, research work, membership, achievements, with photo that will be maximum 200-400 words.

Ibrahim Alrajawy profile which contains their education details, their publications, research work, membership, achievements, with photo that will be maximum 200-400 words.

Amiya Bhaumik profile which contains their education details, their publications, research work, membership, achievements, with photo that will be maximum 200-400 words. 